\title{
Zobellia barbeyronii sp. nov., a New Member of the Family Flavobacteriaceae, Isolated from Seaweed, and Emended Description of the Species Z. amurskyensis, Z. laminariae, Z. russellii and Z. uliginosa
}

\author{
Olga Nedashkovskaya ${ }^{1, *}$, Nadezhda Otstavnykh ${ }^{1}$ (D), Natalia Zhukova ${ }^{2}$ (D), Konstantin Guzev ${ }^{1}$, \\ Viktoria Chausova $^{1}$, Liudmila Tekutyeva ${ }^{3}$, Valery Mikhailov ${ }^{1}$ and Marina Isaeva ${ }^{1, *(D)}$
}

1 G.B. Elyakov Pacific Institute of Bioorganic Chemistry, Far Eastern Branch, Russian Academy of Sciences, 159, Pr. 100 let Vladivostoku, 690022 Vladivostok, Russia; chernysheva.nadezhda@gmail.com (N.O.); k.guzev@gmail.com (K.G.); v.chausova@gmail.com (V.C.); vvmikhailov@inbox.ru (V.M.)

2 A.V. Zhirmunsky National Scientific Center of Marine Biology, Far Eastern Branch, Russian Academy of Sciences, Palchevskogo str. 17, 690041 Vladivostok, Russia; nzhukova35@list.ru

3 Innovative Technology Center, Basic Department of Bioeconomics and Food Security, School of Economics and Management, Far Eastern Federal University, 8 Suhanova St., 690950 Vladivostok, Russia; tekuteva.la@dvfu.ru

check for updates

Citation: Nedashkovskaya, O.; Otstavnykh, N.; Zhukova, N.; Guzev, K.; Chausova, V.; Tekutyeva, L.; Mikhailov, V.; Isaeva, M. Zobellia barbeyronii sp. nov., a New Member of the Family Flavobacteriaceae, Isolated from Seaweed, and Emended Description of the Species $Z$. amurskyensis, Z. laminariae, Z. russellii and Z. uliginosa. Diversity 2021, 13, 520. https://doi.org/10.3390/ d13110520

Academic Editor: Michael Wink

Received: 20 September 2021 Accepted: 19 October 2021 Published: 22 October 2021

Publisher's Note: MDPI stays neutral with regard to jurisdictional claims in published maps and institutional affiliations.

Copyright: (C) 2021 by the authors Licensee MDPI, Basel, Switzerland. This article is an open access article distributed under the terms and conditions of the Creative Commons Attribution (CC BY) license (https:// creativecommons.org/licenses/by/ $4.0 /)$.
* Correspondence: oned2004@mail.ru (O.N.); issaeva@gmail.com (M.I.); Tel.: +7-914-702-0915 (M.I.)

\begin{abstract}
Six Gram-stain-negative, aerobic, rod-shaped, and motile by gliding bacterial strains were isolated from Pacific green and red algae. Phylogenetic analysis based on 16S rRNA gene sequences placed the novel strains into the genus Zobellia as a distinct evolutionary lineage close to Zobellia nedashkovskayae Asnod2-B07-B ${ }^{\mathrm{T}}$ and Zobellia laminariae $\mathrm{KMM} 3676^{\mathrm{T}}$ sharing the highest similarity of $99.7 \%$ and $99.5 \%$, respectively. The average nucleotide identity and the average amino acid identity values between strains 36-CHABK-3-33 ${ }^{\mathrm{T}}$ and Z. nedashkovskayae Asnod2-B07-B ${ }^{\mathrm{T}}$ and Z. laminariae KMM $3676^{\mathrm{T}}$ were $89.7 \% / 92.9 \%$ and $94.2 \% / 95.8 \%$, respectively. The digital DNA-DNA hybridization values based on the draft genomes between strains 36-CHABK-3-33 ${ }^{\mathrm{T}}$ and Z. nedashovskayae Asnod2$\mathrm{B} 07-\mathrm{B}^{\mathrm{T}}$ and Z. laminariae $\mathrm{KMM} 3676^{\mathrm{T}}$ were $39.5 \pm 2.5 \%$ and $59.6 \pm 2.7 \%$, respectively. Multilocus sequence analysis based on house-keeping genes ( $d n a K, g y r B, p y r H, r e c A$ and top $A)$ assigned the alga-associated isolates to the same species, which clustered separately from the recognized species of the genus Zobellia. The strains under study grew at $4-32{ }^{\circ} \mathrm{C}$ and with $0.5-8 \% \mathrm{NaCl}$ and decomposed aesculin, gelatin, DNA, and Tweens 20 and 80, and weakly agar. The DNA G+C content was 36.7\% calculated from genome sequence analysis for the strain $36-\mathrm{CHABK}-3-33^{\mathrm{T}}$. The predominant fatty acids of strain $36-\mathrm{CHABK}-3-33^{\mathrm{T}}$ ( $>5 \%$ of the total fatty acids) were iso- $\mathrm{C}_{17: 0} 3-\mathrm{OH}$, summed feature 3 (comprising $\mathrm{C}_{16: 1} \omega 7 c$ and/or iso- $\mathrm{C}_{15: 0} 2-\mathrm{OH}$ fatty acids), iso- $\mathrm{C}_{15: 0}$, iso- $\mathrm{C}_{15: 1} \mathrm{G}$, and $\mathrm{C}_{15: 0}$. The major polar lipids were phosphatidylethanolamine, three unidentified lipids, and two unidentified aminolipids. The only detected respiratory quinone was MK-6. The significant molecular distinctiveness between the novel isolates and their nearest neighbor was strongly supported by differences in physiological and biochemical tests. Therefore, the six novel strains represent a novel species of the genus Zobellia, for which the name Zobellia barbeyronii sp. nov. is proposed. The type strain is 36-CHABK-3-33 ${ }^{\mathrm{T}}\left(=\right.$ KACC $\left.21790^{\mathrm{T}}=\mathrm{KMM} 6746^{\mathrm{T}}\right)$.
\end{abstract}

Keywords: Zobellia barbeyronii; Flavobacteriaceae; marine bacteria; phylogeny; alga; genome

\section{Introduction}

The genus Zobellia was first described by Barbeyron et al. [1] with Zobellia galactanivorans as the type species. At the time of writing, the genus Zobellia comprises seven species with validly published names (as listed at [2]) that were recovered from different marine 
environments and have a DNA G+C content of $36.7-42.8 \mathrm{~mol} \%$. Species in the genus Zobellia are Gram negative, aerobic, heterotrophic, rod-shaped, non-spore-forming, and gliding bacteria that form orange or yellow colonies and produce flexirubin-type pigments. Most species possess agarolytic activity [1,3,4]. The type strain of the type species of the genus, $Z$. galactanivorans, was isolated from the red alga Delesseria sanguinea, collected in the English Channel near Roscoff (Brittany, France) [1]. Strains of species Z. laminariae and Z. russellii were also isolated from seaweeds: the brown alga Saccharina (formerly Laminaria) japonica and the green alga Acrosiphonia sonderi, respectively, the widespread algae inhabiting the Sea of Japan, the Pacific Ocean [3]. Strains of the recently described species, Z. roscoffensis and Z. nedashkovskayae, were members of the epiphytic communities of the brown alga Ascophyllum nodosum collected in Roscoff (Brittany, France) too [4]. Unlike the above, species Z. amurskyensis was recovered from a seawater sample, collected from Amursky Bay of the Sea of Japan [3]. The species Z. uliginosa, isolated from the surface sediment and originally named as Flavobacterium uliginosum [5], was subsequently placed in the genus Cytophaga as Cytophaga uliginosa [6] and to the genus Cellulophaga as Cellulophaga uliginosa [7]. At present, it is classified in the genus Zobellia because of the close phylogenetic relatedness to members of the genus along with the DNA G+C content, maximum growth temperature, and the presence of flexirubin type pigments [1]. The studies of the genomes of bacteria belonging to the genus Zobellia have confirmed the results of phenotypic tests obtained previously, and significantly expanded our knowledge of the ability of bacteria of this taxonomic group to utilize polysaccharides of marine algae $[4,8-10]$. Moreover, the type strain of the species Z. galactanivorans has been proposed as a model organism for the study of bacteria-algae interactions [9].

In the present work, we report the phenotypic, genomic, and phylogenetic characterization of six Gram-negative, aerobic, dark-orange, motile by gliding, and agarolytic bacterial strains, which were recovered from a green alga Ulva sp. and an unidentified red alga during a survey of the biodiversity of microbial communities of marine organisms living in isolation in Kraternaya Bay near volcano Ushishir (Kuril Islands, Russia). The detail taxonomic analysis based on a polyphasic approach indicated that these alga-associated isolates represent a novel species of the genus Zobellia.

\section{Materials and Methods}

\subsection{Bacterial Isolation and Cultivation}

Strains 36-CHABK-3-33 ${ }^{\mathrm{T}}$, 36-CHABK-3-51, 36-CHABK-3-57, and 36-CHABK-3-61 were isolated from the green alga Ulva sp., and strains 36-RHABK-5-24 and 36-RHABK-554 were isolated from an unidentified red alga (raised from a depth of $53 \mathrm{~m}$ ). All of them were collected in the Kraternaya Bay, Yanchich Island, Kuril Islands, the Sea of Okhotsk (47.510239 N; 152.822071 E) during 36th cruise of R/V "Academic Oparin" in August 2008. The samples of algal fronds ( $5 \mathrm{~g}$ ) were washed twice with sterile seawater to remove loosely attached bacteria and homogenized in $10 \mathrm{~mL}$ sterile seawater in a glass homogenizer and $0.1 \mathrm{~mL}$ homogenate was spread onto marine agar 2216 (MA, BD, Difco, Sparks, MD, USA) plates using a dilution plating method. Each novel isolate was obtained from a single colony after incubation of the plate at $28^{\circ} \mathrm{C}$ for 7 days. After primary isolation and purification, the strains were cultivated at $25-28{ }^{\circ} \mathrm{C}$ on the same medium and stored at $-80{ }^{\circ} \mathrm{C}$ in marine broth (Difco) supplemented with $20 \%(v / v)$ glycerol.

\section{2. $16 S$ rRNA Gene Sequencing and Phylogenetic Analysis}

DNAs were extracted from bacterial cultures using the NucleoSpin Microbial DNA Mini kit (Macherey-Nagel, Düren, Germany), following the manufacturer's instructions. The 16S rRNA genes were amplified with the 27F (5'-AGAGTTTGATCMTGGCTCAG$\left.3^{\prime}\right)$ and 1492R (5'-TACGGTTACCTTGTTACGACTT- $\left.3^{\prime}\right)$ primers [11] and were sequenced on an ABI Prism 3130 xL DNA analyzer (Applied Biosystems, Hitachi, Japan) using the Big Dye Terminator reagent kit, version 3.1. The gene sequences of the strains were deposited in GenBank/EMBL/DDBJ under the accession numbers from MZ890274 to 
MZ890278. The 16S rRNA gene sequence analysis for identification of the strains was performed using the EzBioCloud [12]. The 16S rRNA gene sequences were aligned by Clustal W [13]. Phylogenetic analysis was carried out using the maximum-likelihood (ML), neighbor-joining (NJ), and maximum-parsimony (MP) algorithms implemented in the MEGA7 software [14]. The genetic distances were calculated according to the Kimura twoparameter model [15]. Bootstrap values were calculated from 500-1000 alternative trees.

\subsection{Multilocus Sequence Analysis (MLSA)}

The multilocus sequence analysis (MLSA) was conducted using concatenated sequences of five housekeeping genes, namely dnaK (Chaperone protein DnaK), gyrB (DNA gyrase, B subunit), pyrH (Uridylate kinase), recA (Recombinase A), and topA (DNA topoisomerase I). The MLSA primers were designed based on genome sequence of the 36CHABK-3-33 ${ }^{\mathrm{T}}$ using the Vector NTI software package version 11.0 (Invitrogen, Carlsbad, CA, USA) (Table S1). Primer sequences were examined further to confirm that no secondary structures were likely to form. The sequences of strain $36-\mathrm{CHABK}-3-33^{\mathrm{T}}$ and other members of the genus Zobellia were retrieved from their whole genome sequences. The partial sequences of the remaining five isolates were obtained by amplification and sequencing of the corresponding genes. The gene sequences of five strains were deposited in GenBank/EMBL/DDBJ under the accession numbers from MZ911872 to MZ911896. The sequences obtained were then concatenated, aligned, and used to reconstruct ML, MP, and NJ phylogenetic trees in the MEGA7 software [14]. The genetic variability across the five genes of the MLSA analyses was estimated using the Kimura 2-parameter model with $1 \mathrm{st}+2 \mathrm{nd}+3 \mathrm{rd}+$ Noncoding codon positions. Split decomposition analysis was performed for the concatenated genes using SplitsTree version 4.14.3 with a neighbor net drawing and a Jukes-Cantor correction [16].

\subsection{Genome Features of Strain 36-CHABK-3-33 $3^{T}$ and Phylogenomic Reconstruction}

The genomic DNA was obtained from the strain $36-\mathrm{CHABK}-3-33^{\mathrm{T}}$ cells as described above in the Section 2.2 using the NucleoSpin Microbial DNA Mini kit (Macherey-Nagel, Düren, Germany). Whole-genome shotgun sequencing of the strain $36-\mathrm{CHABK}-3-33^{\mathrm{T}}$ was carried out at an Illumina MiSeq platform using Nextera DNA Flex kits (Illumina, San Diego, CA, USA) and a 150-bp paired-end kit (Illumina, San Diego, CA, USA). The sequence quality was assessed via FastQC version 0.11 .8 [17] and reads were trimmed using Trimmomatic version 0.38 [18]. Filtered reads were assembled de novo with SPAdes version 3.13.1 [19] and assembly metrics were calculated with QUAST version 5.0.2 [20]. The genome completeness was further evaluated by checkM version 1.1.3 based on the taxonomic-specific workflow (family Flavobacteriaceae) [21]. The draft genome of strain 36-CHABK-3-33 ${ }^{\mathrm{T}}$ was annotated using NCBI Prokaryotic Genome Annotation Pipeline (PGAP) [22] and its features are summarized in Table 1. The genome of strain 36-CHABK-3-33 ${ }^{\mathrm{T}}$ was deposited in GenBank/EMBL/DDBJ under the accession number JACATN000000000.1.

The phylogenetic analysis was performed with PhyloPhlAn 3.0 using 400 conserved protein sequences [23]. The Average Nucleotide Identity (ANI) and Amino Acid Identity (AAI) values were calculated with the online server ANI/AAI-Matrix [24]. Values of in silico DNA-DNA hybridization ( $\mathrm{dDDH})$ of the strain $36-\mathrm{CHABK}-3-33^{\mathrm{T}}$ and its closest relatives were measured at TYGS platform [25]. To identify carbohydrate-active enzymes (CAZymes) in the Zobellia genomes, we used the dbCAN2 meta server (http:/ / cys.bios. niu.edu/dbCAN2, accessed on 18 December 2020) [26]. Predictions by at least one of the three algorithms integrated within the server (DIAMOND, HMMER, and Hotpep) were considered sufficient for CAZy family assignments. 
Table 1. General genomic features of the strain $36-\mathrm{CHABK}-3-33^{\mathrm{T}}$ and other species of the genus Zobellia.

\begin{tabular}{|c|c|c|c|c|c|c|c|c|}
\hline Feature & 1 & 2 & 3 & 4 & 5 & 6 & 7 & 8 \\
\hline Assembly level & Contig & Contig & Contig & Contig & Contig & Contig & $\begin{array}{l}\text { Complete } \\
\text { Genome }\end{array}$ & Contig \\
\hline Genome size $(\mathrm{Mb})$ & 4.98 & 4.94 & 5.15 & 5.14 & 4.98 & 5.30 & 5.52 & 4.92 \\
\hline Number of contigs & 37 & 2 & 27 & 120 & 3 & 27 & 1 & 49 \\
\hline $\mathrm{G}+\mathrm{C}$ Content $(\%)$ & 36.7 & 36.8 & 36.8 & 38.0 & 37.6 & 42.6 & 42.8 & 39.0 \\
\hline N50 (bp) & 927.759 & 4.937 .885 & 904.812 & 94.524 & 4.613 .932 & 914.779 & & 644.008 \\
\hline L50 (bp) & 3 & 1 & 3 & 17 & 1 & 3 & & 3 \\
\hline Coverage & 24 & 224 & 75 & 16 & 253 & 254 & & 27 \\
\hline Total genes & 4114 & 4074 & 4285 & 4241 & 4041 & 4381 & 4486 & 4025 \\
\hline $\begin{array}{l}\text { Protein coding } \\
\text { genes }\end{array}$ & 4053 & 4013 & 4177 & 4157 & 3981 & 4298 & 4416 & 3967 \\
\hline $\begin{array}{c}\text { rRNAs(5S/16S/23S) } \\
\text { tRNA }\end{array}$ & $\begin{array}{c}1 / 1 / 1 \\
39\end{array}$ & $\begin{array}{c}2 / 1 / 1 \\
39\end{array}$ & $\begin{array}{c}1 / 1 / 1 \\
39\end{array}$ & $\begin{array}{c}1 / 1 / 1 \\
37\end{array}$ & $\begin{array}{c}2 / 1 / 1 \\
38\end{array}$ & $\begin{array}{c}1 / 1 / 1 \\
37\end{array}$ & $\begin{array}{c}2 / 2 / 2 \\
40\end{array}$ & $\begin{array}{c}1 / 1 / 2 \\
36\end{array}$ \\
\hline $\begin{array}{c}\text { checkM } \\
\text { completeness (\%) }\end{array}$ & 100.00 & 100.00 & 99.68 & 100.00 & 100.00 & 100.00 & 100.00 & 99.68 \\
\hline $\begin{array}{c}\text { checkM } \\
\text { contamination (\%) }\end{array}$ & 1.07 & 1.07 & 1.07 & 0.97 & 0.65 & 0.81 & 1.07 & 0.00 \\
\hline Accession number & $\begin{array}{c}\text { JACATN000 } \\
000000.1\end{array}$ & $\begin{array}{l}\text { JADDXR000 } \\
000000.1\end{array}$ & $\begin{array}{c}\text { RCNS000 } \\
00000.1\end{array}$ & $\begin{array}{c}\text { RCNR000 } \\
00000.1\end{array}$ & $\begin{array}{c}\text { JADDXT000 } \\
000000.1\end{array}$ & $\begin{array}{c}\text { FTOB000 } \\
00000.1\end{array}$ & FP476056.1 & $\begin{array}{c}\text { JACSOI000 } \\
000000.1\end{array}$ \\
\hline
\end{tabular}

Strains: (1) 36-CHABK-3-33 ${ }^{\mathrm{T}}$; (2) Zobellia nedashkovskayae Asnod2-B07-B ${ }^{\mathrm{T}}$; (3) Zobellia laminariae $\mathrm{KMM}^{3676^{\mathrm{T}}}$; (4) Zobellia amurskyensis KMM

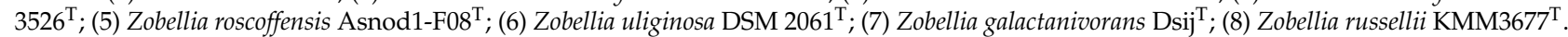

\subsection{Physiology and Chemotaxonomy}

The physiological, morphological, and biochemical properties of the novel strains were studied using standard methods. Cell morphology was examined using transmission electron microscopy using cells growing for $48 \mathrm{~h}$ on $\mathrm{MA}$ at $28^{\circ} \mathrm{C}$. Gliding motility was assessed as described by Bowman [7]. Gram-staining was performed as recommended by Smibert and Krieg [27]. Oxidative or fermentative utilization of glucose was determined on Hugh \& Leifson's medium modified for marine bacteria [28]. Catalase activity was tested by addition of $3 \%(v / v) \mathrm{H}_{2} \mathrm{O}_{2}$ solution to a bacterial colony and observation for the appearance of gas. Oxidase activity was determined by using $N, N, N, N$-tetramethyl-pphenylenediamine. Degradation of agar, starch, casein, gelatin, and DNA, growth at $\mathrm{pH}$ 5-11 range (using increments of $1 \mathrm{pH}$ unit), and production of acid from carbohydrates, hydrolysis of Tweens 20,40, and 80, nitrate reduction, and production of hydrogen sulphide were tested according to standard methods [27]. Flexirubin pigments were detected with the Fautz and Reichenbach method [29]. Biochemical features and enzyme activities of the novel isolates were also examined using API 20E, API 20NE, API 50CH, and API ZYM galleries (BioMérieux, Marcy-l'Étoile, France) according to the manufacturer's instructions. All galleries were incubated at $28{ }^{\circ} \mathrm{C}$. The temperature range for growth was $4-45^{\circ} \mathrm{C}$ at intervals of $1^{\circ} \mathrm{C}$ and assessed on MA. Tolerance to $\mathrm{NaCl}$ was checked in medium containing $5 \mathrm{~g}$ Bacto Peptone (Difco), $2 \mathrm{~g}$ Bacto yeast extract (Difco), $1 \mathrm{~g}$ glucose, $0.2 \mathrm{~g} \mathrm{~K}_{2} \mathrm{HPO}_{4}, 0.64 \mathrm{~g}$ $\mathrm{KCl}, 1.3 \mathrm{~g} \mathrm{CaCl}_{2} \cdot 2 \mathrm{H}_{2} \mathrm{O}$, and $5.05 \mathrm{~g} \mathrm{MgSO}_{4} \cdot 7 \mathrm{H}_{2} \mathrm{O}$ per liter of distilled water with $0,0.5,1.0$, $1.5,2.0,2.5,3,4,5,6,8,10$, and $12 \%(w / v)$ of $\mathrm{NaCl}$. Susceptibility to antibiotics was examined by the routine disc diffusion plate method. Discs were impregnated with the following antibiotics: ampicillin $(10 \mu \mathrm{g})$, benzylpenicillin $(10 \mathrm{U})$, carbenicillin $(100 \mu \mathrm{g})$, cefalexin $(30 \mu \mathrm{g})$, cefazolin $(30 \mu \mathrm{g})$, chloramphenicol $(30 \mu \mathrm{g})$, erythromycin $(15 \mu \mathrm{g})$, doxycycline $(10 \mu \mathrm{g})$, gentamicin $(10 \mu \mathrm{g})$, kanamycin $(30 \mu \mathrm{g})$, lincomycin $(15 \mu \mathrm{g})$, nalidixic acid $(30 \mu \mathrm{g})$, neomycin $(30 \mu \mathrm{g})$, ofloxacin $(5 \mu \mathrm{g})$, oleandomycin $(15 \mu \mathrm{g})$, oxacillin $(10 \mu \mathrm{g})$, polymyxin B (300 U), rifampicin $(5 \mu \mathrm{g})$, streptomycin $(30 \mu \mathrm{g})$, tetracycline $(5 \mu \mathrm{g})$ and vancomycin $(30 \mu \mathrm{g})$.

For determination of whole-cell fatty acid and polar lipid profiles, strains 36-CHABK3-33 ${ }^{\mathrm{T}}$, Z. galactanivorans CIP $106680^{\mathrm{T}}$, Z. amurskyensis KMM $3526^{\mathrm{T}}$, Z. laminariae KMM $3676^{\mathrm{T}}$, Z. russellii $\mathrm{KMM} 3677^{\mathrm{T}}$, and Z. uliginosa DSM $2061^{\mathrm{T}}$ were grown for $48 \mathrm{~h}$ on MA. Cellular fatty acid methyl esters were prepared according to the standard protocol of the Microbial Identification System (MIDI, version 3.5) [30] and analysed using a GC-17A chromatograph (Shimadzu, Kyoto, Japan) equipped with a fused silica capillary column $(30 \mathrm{~m} \times 0.25 \mathrm{~mm})$ coated with Supercowax-10 and SPB-5 phases (Supelco, Bellefonte, PA, USA) at $210{ }^{\circ} \mathrm{C}$. FAMES were identified using equivalent chain length measurements and by comparing of retention times those of authentic standards. FAMEs were also analysed by GC-MS 
(Shimadzu QP5050A) equipped with an MDN-5S capillary column $(30 \mathrm{~m} \times 0.25 \mathrm{~mm})$ at temperature of the injector and detector of $250^{\circ} \mathrm{C}$. Polar lipids were determined by TLC as described by Minnikin et al. [31].

The isoprenoid quinone composition of strain $36-\mathrm{CHABK}-3-33^{\mathrm{T}}$ was characterized by HPLC (Shimadzu LC-10A) using a reversed-phase type Supelcosil LC-18 column $(15 \mathrm{~cm} \times 4.6 \mathrm{~mm})$ and acetonitrile/2-propanol $(65: 35, v / v)$ as a mobile phase at a flow rate of $0.5 \mathrm{~mL} \mathrm{~min}{ }^{-1}$. The column was kept at $40{ }^{\circ} \mathrm{C}$. Menaquinones were detected by monitoring at $270 \mathrm{~nm}$.

\section{Results and Discussion}

\subsection{Phylogenetic Analysis}

Nearly full-length $16 \mathrm{~S}$ rRNA gene sequences (1384 bp) of the six isolates were determined and aligned with corresponding sequences of members of the genus Zobellia, which were retrieved from genomic sequences. The phylogenetic trees based on 16S rRNA gene sequences reconstructed with NJ, ML, and MP algorithms showed highly similar branch topology. According to the ML tree (Figure 1), the six isolates clustered together, and were most closely related to the Z. nedashkovskayae ( $99.7 \%$ of sequence similarity), followed by Z. laminariae (99.5\%), and Z. amurskyensis (98.8\%).

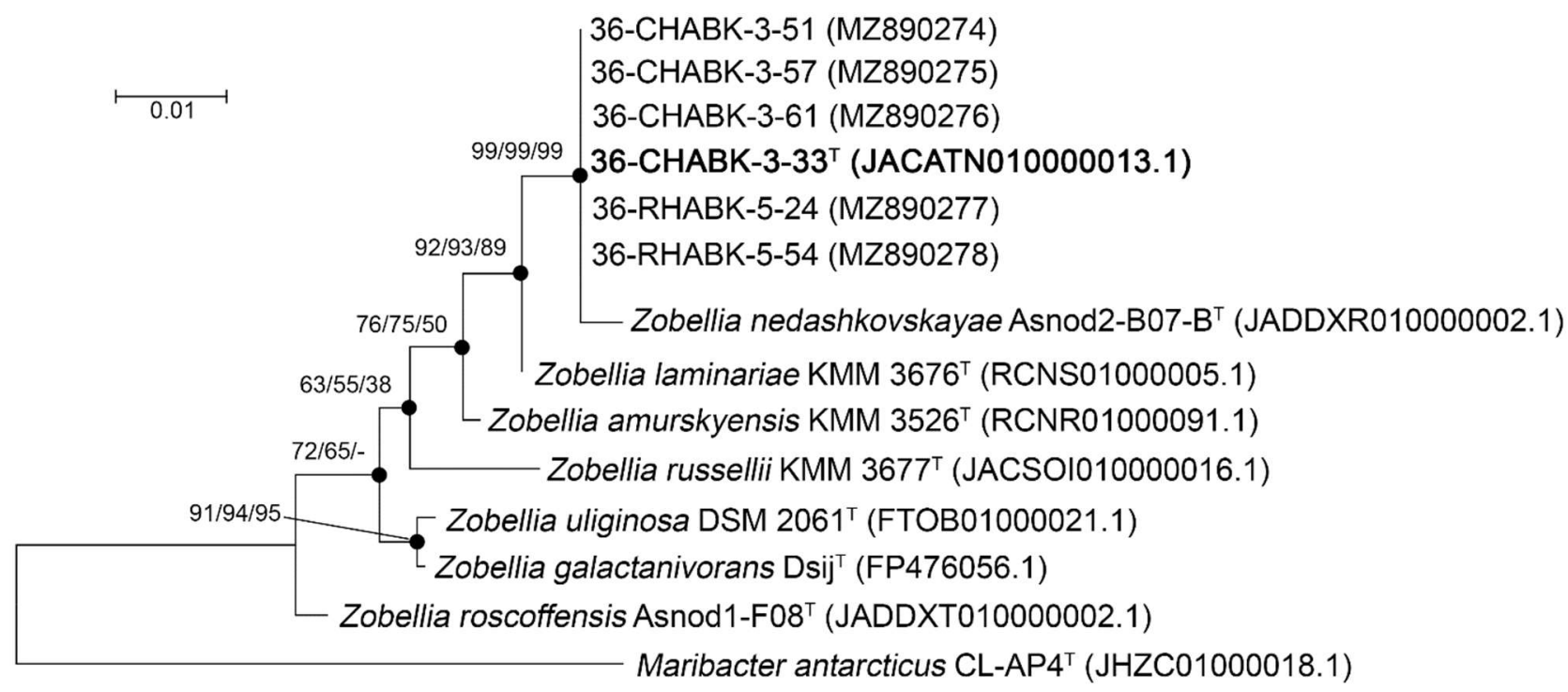

Figure 1. Maximum-likelihood (ML) phylogenetic tree based on 16S rRNA gene sequences, showing the phylogenetic position of six alga-associated isolates and other members of the genus Zobellia. The ML tree was inferred using the K2+G model recommended by MEGA v.7. Bootstrap values in the order ML/NJ/MP are based on 500/1000/500 replications. Bar, 0.01 substitutions per nucleotide position.

The phylogenetic analysis revealed that the six strains belong to the genus Zobellia and cluster with Z. nedashkovskayae Asnod2-B07-B ${ }^{\mathrm{T}}$ but form a separate branch supported by high bootstrap values of $99 \%$. It indicates that the novel strains could represent a new species of the genus Zobellia.

\subsection{Multilocus Sequence Analysis of the Alga-Associated Isolates}

The 16S rRNA sequences provided insufficient phylogenetic resolution of the six isolates at the strain level. To elucidate phylogenetic relationships among the six isolates without whole genome sequencing, we developed an MLSA based on the five housekeeping genes: $d n a K, g y r B, p y r H, r e c A$, and top $A$. In addition, we performed a concatenated sequence analysis because it can more accurately predict intraspecific relationships. Based on the ML, MP, and NJ phylogenies (Figure S1), and split tree decomposition analysis (Figure 2), the MLSA placed all isolates in a separate branch within the clade with Z. laminariae and 
Z. nedashkovskayae. The resulting tree also confirmed the branch topology of the $16 \mathrm{~S}$ rRNA gene tree and the genetic variability of the six alga-associated isolates. The MLSA distances between the isolates were $0.000-0.014$ (average value was $0.010 \pm 0.002$ ), and between the isolates and two type strains Z. nedashkovskayae and Z. laminariae were $0.053 \pm 0.005$ and $0.055 \pm 0.005$, respectively (Table S2).

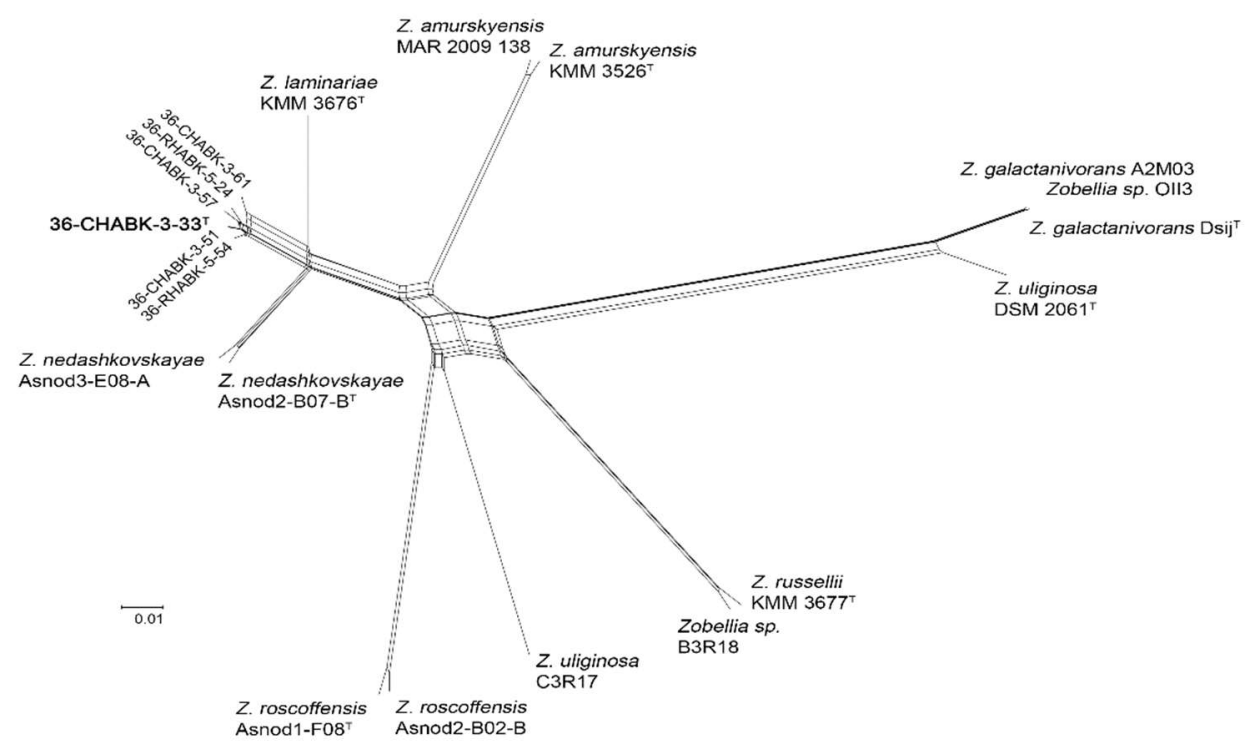

Figure 2. Split network tree of Zobellia strains based on concatenated partial dnaK-gyrB-pyrH-recAtopA (2570 bp) gene sequences by SplitsTree4 program [16].

\subsection{Genomic Characteristics and Phylogenomic Analysis}

The 16S rRNA gene analysis showed close relationship of the six bacterial isolates to Z. nedashkovskayae Asnod2-B07- ${ }^{\mathrm{T}}$, sharing about $99.7 \%$ of sequence similarity. Therefore, the whole genome sequence of strain $36-\mathrm{CHABK}-3-33^{\mathrm{T}}$ was determined using Illumina MiSeq platform. The draft genome was de novo assembled into 37 contigs, with a N50 value of $927,759 \mathrm{bp}$, and a L50 value of three (Table 1). The genome size was estimated at $4,977,540 \mathrm{bp}$ in length with a coverage of $24 \times$. The $\mathrm{G}+\mathrm{C}$ content was $36.7 \mathrm{~mol} \%$. The genome size and $\mathrm{G}+\mathrm{C}$ content were within the range of values typical for the genus Zobellia, which ranged from 36.7 to $42.8 \mathrm{~mol} \%$, and from 4.92 to $5.52 \mathrm{Mb}$, respectively [10].

The characteristics of strain $36-\mathrm{CHABK}-3-33^{\mathrm{T}}$ draft genome were compared to those of publicly available genomes of other Zobellia species. The genome completeness was $100 \%$ which is comparable with the estimated completeness of other Zobellia genomes, suggesting high assembly quality with of $0-1.07 \%$ of contamination among all the genomes (Table 1).

The genomic tree constructed with PhyloPhlAn3.0 [23] using concatenated sequences of 400 conserved proteins clarified the phylogenetic position of the novel species Z. barbeyronii, which is closer to Z. laminariae than to Z. nedashkovskayae (Figure 3).

To quantify the relatedness of $36-\mathrm{CHABK}-3-33^{\mathrm{T}}$ to other Zobellia strains, the ANI, AAI, and dDDH values were calculated on online servers ANI/AAI-Matrix [24] and TYGS platform [25], respectively. The ANI/AAI values between strain 36-CHABK-3-33 ${ }^{\mathrm{T}}$ and phylogenetically closest neighbors Z. nedashkovskayae Asnod2-B07-B ${ }^{\mathrm{T}}$ and Z. laminariae KMM $3676^{\mathrm{T}}$ were $89.7 \% / 92.9 \%$ and $94.2 \% / 95.8 \%$, respectively. The obtained ANI values were lower than ANI threshold of $95 \%$, which is recommended for species delineation [32,33]. The dDDH values (formula $\mathrm{d}_{4}$ ) between strain $36-\mathrm{CHABK}-3-33^{\mathrm{T}}$ and two closest neighbors Z. laminariae KMM $3676^{\mathrm{T}}$ and Z. nedashkovskayae Asnod2-B07-B ${ }^{\mathrm{T}}$ were $59.6 \pm 2.7 \%$ and $39.5 \pm 2.5 \%$, respectively. The obtained $\mathrm{dDDH}$ relatedness values were below the threshold value for species boundaries of 70\% [34]. These data clearly show that strain 36-CHABK-3-33 ${ }^{\mathrm{T}}$ represents a novel species within the genus Zobellia. 


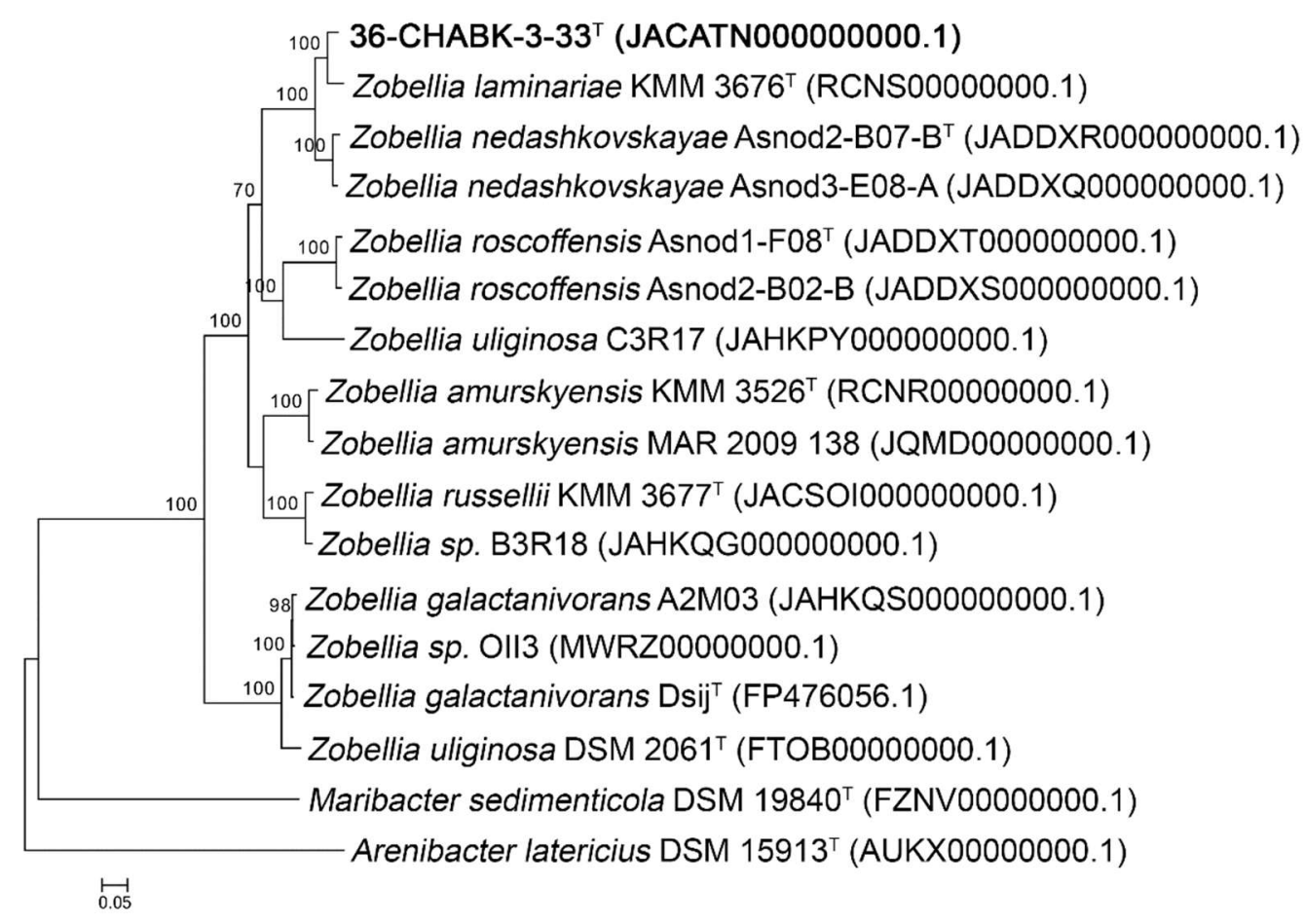

Figure 3. Maximum-likelihood phylogeny of available genomes of the genus Zobellia and strain 36-CHABK-3-33 ${ }^{\mathrm{T}}$ based on 400 universal markers selected by PhyloPhlAn3.0 and reconstructed by RAxML with non-parametric bootstrapping using 100 replicates including Bar, 0.05 substitutions per amino acid position.

It has been known, that Zobellia genomes are rich in CAZymes genes [9,10,35]. The genome of strain $36-\mathrm{CHABK}-3-33^{\mathrm{T}}$ has a high proportion of CAZymes accounting to $6.55 \%$ $\left(6.63 \%\right.$ in Z. nedashkorskayae Asnod2-B07- $\mathrm{B}^{\mathrm{T}}$ and $6.61 \%$ in Z. laminariae $\left.\mathrm{KMM} 3676^{\mathrm{T}}\right)$, which indicates a special role in the environment as a carbohydrate specialist. The CAZome of strain 36-CHABK-3-33 ${ }^{\mathrm{T}}$ consists of 130 glycoside hydrolases (GHs) classified into 47 families, 63 glycosyltransferases (GTs) of 14 families, 19 polysaccharide lyases (PLs) of 9 families, 14 carbohydrate esterases (CEs) of 7 families, 53 carbohydrate-binding modules (CBMs) of 15 families, and 10 auxiliary activities (AAs) of 5 families. Recently, a detailed investigation of PL7 alginate lyase genes across the Zobellia genus has been performed [35]. We found that strain $36-\mathrm{CHABK}-3-33^{\mathrm{T}}$ (as well as Z. nedashkorskayae) possesses the highest number of PL7s, which belong to several subfamilies and distributed over separate genetic loci. In addition, a detail inspection of the Zobellia species CAZome revealed members of new family of GH168, recently described for marine bacterium Wenyingzhuangia fucani-

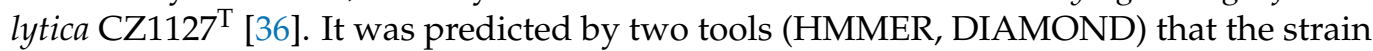
36-CHABK-3-33 ${ }^{\mathrm{T}}$ genome codes the gene for endo-1,3-fucanase (MBT2161531.1), which cleaves $\alpha-1,3$ glycosidic linkage in sulfated fucans. The phylogenetic analysis of GH168 (Figure 4) showed that MBT2161531.1 is clustered together with FunA. MBT2162796.1 and proteins from the Z. nedashkovskayae strains predicted only by HMMER were used as an outgroup. Therefore, putative PL7s and GH168 of strain $36-\mathrm{CHABK}-3-33^{\mathrm{T}}$ are of particular interest as promising biocatalysts for degradation of polysaccharides. 


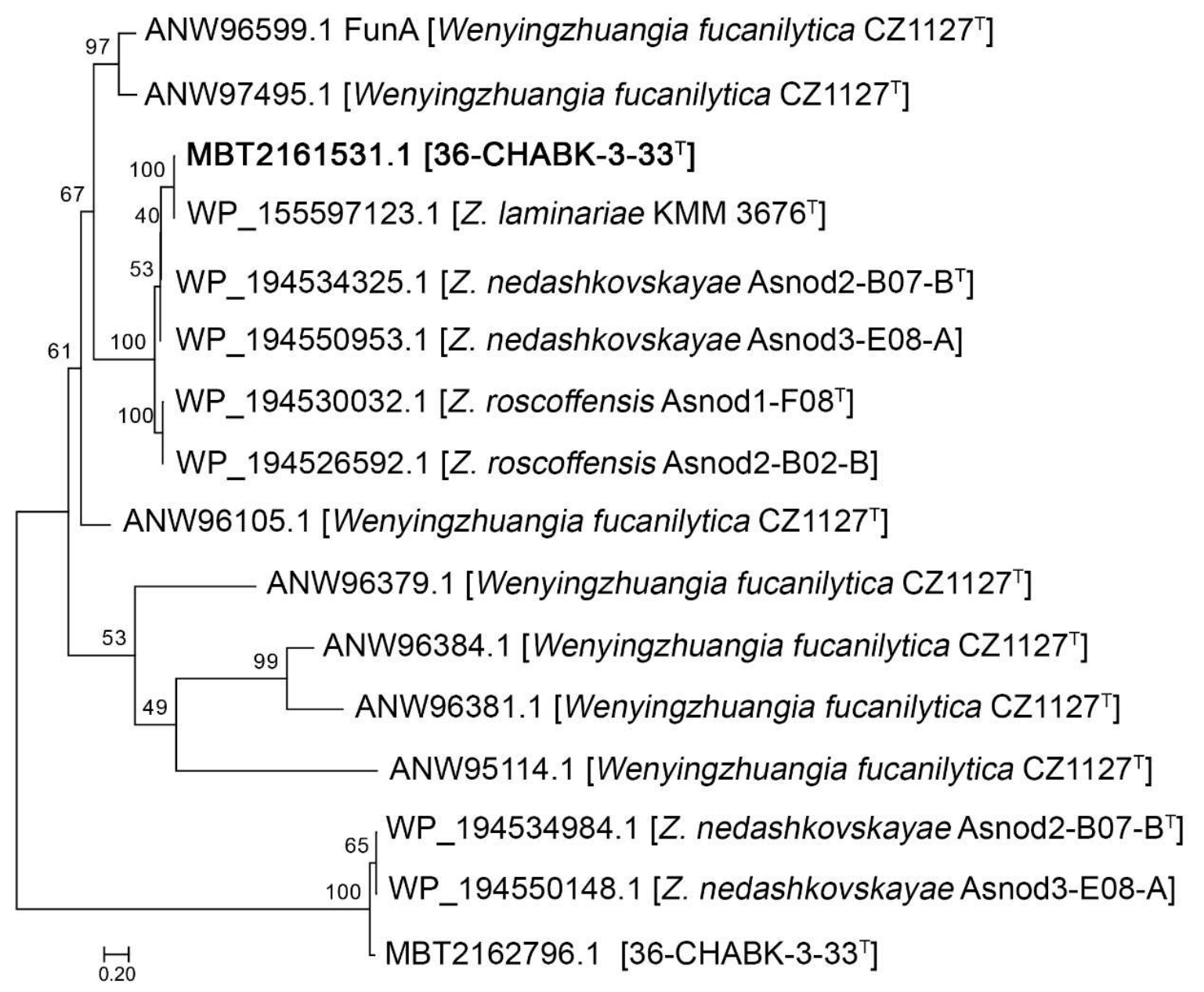

Figure 4. Maximum-likelihood phylogenetic tree of GH168 family endo-1,3-fucanase from Zobellia and selected characterized representatives of GH168 family. The ML tree was inferred using the WAG+G+I model recommended by MEGA v.7. For characterized and predicted GH168 family members, the corresponding GenBank accession numbers are given. The organism names are listed in brackets.

\subsection{Morphological, Physiological and Biochemical Characteristics}

The detailed phenotypic characteristics of the new strains are given in Table 2 and in the species description. The alga-associated isolates possessed several common properties with validly published species of the genus Zobellia, including the requirement of sea salts or seawater for growth, hydrolysis of aesculin, agar, gelatin, and tyrosine and production of flexirubin-type pigments (Table 2). However, they could be differentiated from their closest relative, Z. laminariae, by their ability to degrade DNA, Tweens 20 and 80 , and to produce acid from D-xylose (Table 2 ). The maximum temperature and minimum salinity for growth, along with production of gelatinase and $\alpha$-chymotrypsin clearly separated the strains studied from another nearest neighbor, Z. nedashkovskayae (Table 2). Several phenotypic traits presented in Table 2 can be helpful for discrimination of the new strains from the type species of the genus Zobellia. 
Table 2. Phenotypic characteristics, differentiating six alga-associated isolates and closely related species of the genus Zobellia.

\begin{tabular}{|c|c|c|c|c|}
\hline Characteristic & 1 & 2 & 3 & 4 \\
\hline Source of isolation * & $\begin{array}{l}\text { Green and red } \\
\text { algae }\end{array}$ & Brown alga & Brown alga & Red alga \\
\hline Temperature range for growth $\left({ }^{\circ} \mathrm{C}\right)$ & $4-32$ & $4-40 *$ & $4-30$ & $4-42$ \\
\hline $\begin{array}{c}\text { Salinity range for growth }(\% \mathrm{NaCl}) \\
\text { Degradation of }\end{array}$ & \multicolumn{3}{|c|}{ Degradation of } & $0.5-8$ \\
\hline Casein & - & - & - & + \\
\hline Gelatin & + & - & + & + \\
\hline Starch & - & $-*$ & - & + \\
\hline DNA & + & + & - & - \\
\hline Tween 20 & + & + & - & + \\
\hline Tween 40 & - & $+*$ & + & - \\
\hline Tween 80 & + & $\mathrm{V}$ & - & - \\
\hline \multicolumn{5}{|l|}{ Acid formation from } \\
\hline L-Rhamnose & + & $+*$ & + & - \\
\hline Raffinose & - & $-*$ & + & - \\
\hline D-Xylose & + & + & - & - \\
\hline$N$-Acetyl-glucosamine & - & $+*$ & - & - \\
\hline Cystine arylamidaseactivity & + & $+*$ & - & + \\
\hline$\alpha$-Chymotrypsin & - & $+{ }^{*}$ & - & - \\
\hline DNA G+C content $(\mathrm{mol} \%)$ & 36.7 & $37.6-37.7 *$ & 36.8 & 42.8 \\
\hline
\end{tabular}

Species: (1) alga-associated isolates $(n=6)$; (2) Zobellia nedashkovskayae Asnod2-B07-B ${ }^{\mathrm{T}}$ and Asnod3-E08-A; (3) Zobellia laminariae KMM $3676^{\mathrm{T}}$; (4) Zobellia galactanivorans CIP $106680^{\mathrm{T}}$. All strains were positive for the following tests: gliding motility, catalase, oxidase, alkaline phosphatase, leucine arylamidase, valine arylamidase, acid phosphatase, naphthol-AS-BI-phosphohydrolase, $\beta$-galactosidase, $\beta$-glucosidase and $\mathrm{N}$-acetyl- $\beta$-glucosamidase activities, nitrate reduction, hydrolysis of aesculin and tyrosine, production of flexirubin-type pigments, production of brown pigment on tyrosine, utilization of L-arabinose, D-glucose, maltose, D-mannose, and mannitol, susceptibility to carbenicillin, lincomycin and rifampicin, resistance to benzylpenicillin, kanamycin, neomycin, oxacillin and polymyxin B. All strains were negative for: acetoin, indole and $\mathrm{H}_{2} \mathrm{~S}$ production, lipase (C14) and $\beta$-glucuronidase activities. Data were obtained from this study unless indicated. v "variable reaction"; *, data from Barbeyron et al. [4].

\subsection{Chemotaxonomic Characterization}

The prevalent fatty acids of strain $36-\mathrm{CHABK}-3-33^{\mathrm{T}}$ were iso- $\mathrm{C}_{17: 0} 3-\mathrm{OH}(21.1 \%)$, summed feature 3 (comprising $\mathrm{C}_{16: 1} \omega 7 \mathrm{c}$ and/or iso- $\mathrm{C}_{15: 0} 2-\mathrm{OH}$ fatty acids; $17.1 \%$ ), iso$\mathrm{C}_{15: 0}(14 \%)$, iso- $\mathrm{C}_{15: 1} \mathrm{G}(13.5 \%), \mathrm{C}_{15: 0}(11.1 \%)$, and iso- $\mathrm{C}_{15: 0} 3-\mathrm{OH}(5.2 \%)$. The presence of iso- $\mathrm{C}_{17: 0} 3-\mathrm{OH}$, summed feature 3 (comprising $\mathrm{C}_{16: 1} \omega 7 \mathrm{c}$ and/or iso- $\mathrm{C}_{15: 0} 2-\mathrm{OH}$ fatty acids), iso- $C_{15: 0}$, iso- $C_{15: 1} G, C_{15: 0}$, iso- $C_{15: 0} 3-O H$, and iso- $C_{17: 1} \omega 8 c$ fatty acids is characteristic for all strains included in this study but strain $36-\mathrm{CHABK}-3-33^{\mathrm{T}}$ differed from them by the presence of $\mathrm{C}_{15: 0} 3-\mathrm{OH}$ and the absence of $\mathrm{C}_{16: 0}$ fatty acids (Table 3). Additionally, there were significant differences in the proportions of some fatty acids between strain 36-CHABK-3-33 $33^{\mathrm{T}}$ and its closest phylogenetic neighbors (Table 3 ). The polar lipid profile of the novel strain was found to be composed of phosphatidylethanolamine, two unidentified aminolipids, and three unidentified lipids; it was similar to the type strain of Z. laminariae and in line with other reference strains (Figure 5). During these experiments the polar lipid profiles were determined for the type strains of species Z. amurskyensis $\mathrm{KMM} 3526^{\mathrm{T}}$, Z. russellii KMM $3677^{\mathrm{T}}$, and Z. uliginoza CIP $104808^{\mathrm{T}}$ too (Figure 5). The sole respiratory quinone of the strain $36-\mathrm{CHABK}-3-33^{\mathrm{T}}$ was menaquinone 6 , which agrees with the quinone patterns reported for members of the genus Zobellia and family Flavobacteraceae [8,37].

Table 3. Cellular fatty acid composition (\%) of strain $36-\mathrm{CHABK}-3-33^{\mathrm{T}}$ and related species of the genus Zobellia.

\begin{tabular}{|c|c|c|c|c|}
\hline Fatty Acid & 1 & $2 *$ & 3 & 4 \\
\hline $\begin{array}{c}\text { Branched } \\
\text { iso- } C_{15: 0} \\
\text { anteiso-- } C_{15: 0} \\
\text { iso- } C_{15: 1} \mathrm{G} \\
\text { iso-- } C_{17: 1} \omega 8 c \\
\text { iso- }_{17: 1} \omega 9 c \\
\text { Saturated } \\
C_{15: 0} \\
C_{16: 0} \\
\text { Unsaturated }\end{array}$ & $\begin{array}{c}14.0 \\
1.7 \\
13.5 \\
3.8 \\
-\end{array}$ & $\begin{array}{c}20.9 \\
1.3 \\
10.7 \\
- \\
7.9\end{array}$ & $\begin{array}{c}17.4 \\
2.0 \\
14.4 \\
3.0 \\
-\end{array}$ & $\begin{array}{c}17.1 \\
1.9 \\
14.9 \\
7.5 \\
-\end{array}$ \\
\hline
\end{tabular}


Table 3. Cont.

\begin{tabular}{|c|c|c|c|c|}
\hline Fatty Acid & 1 & $2 *$ & 3 & 4 \\
\hline$C_{15 ; 1} \omega 6 c$ & 3.9 & 1.7 & 1.0 & 1.8 \\
\hline $\mathrm{C}_{17: 1} \omega 6 c$ & 1.9 & 1.0 & - & $\operatorname{tr}$ \\
\hline $\mathrm{C}_{18: 1}^{11.1} \omega 5 c$ & - & 1.5 & - & - \\
\hline Hydroxy & & & & \\
\hline iso-C $15: 03-\mathrm{OH}$ & 5.2 & 3.6 & 5.4 & 6.4 \\
\hline iso- $\mathrm{C}_{17: 0} 3-\mathrm{OH}$ & 21.1 & 21.2 & 29.1 & 27.1 \\
\hline $\mathrm{C}_{15: 0} 3-\mathrm{OH}$ & 1.1 & - & - & $\operatorname{tr}$ \\
\hline $\mathrm{C}_{16: 0}^{15-\mathrm{O}} \mathrm{OH}$ & 3.5 & 1.1 & 5.6 & 2.6 \\
\hline Summed feature 3 & 17.1 & 13.8 & 13.0 & 9.6 \\
\hline Summed feature 4 & & 1.0 & & \\
\hline
\end{tabular}

Strains: (1) 36-CHABK-3-33 ${ }^{\mathrm{T}}$; (2) Zobellia nedashkovskayae Asnod2-B07-B ${ }^{\mathrm{T}}$; (3) Zobellia laminariae KMM $3676^{\mathrm{T}}$, (4) Zobellia galactanivorans $\mathrm{CIP} 106680^{\mathrm{T}}$. Data were obtained from this study unless indicated. - "not detected"; $\operatorname{tr}$ "trace amount" $(<1 \%)$. Values are percentages of total fatty acids; those fatty acids for which the mean amount in all taxa was less than $1 \%$ are not given. Summed features 3 and 4 consist of the following fatty acids which could not be separated by the Microbial Identification System: one or more of $\mathrm{C}_{16: 1} \omega 7 \mathrm{c}$ and iso- $\mathrm{C}_{15: 0} 2-\mathrm{OH}$, and iso- $\mathrm{C}_{17: 1} \mathrm{I}$ and/or anteiso- $\mathrm{C}_{17: 1} \mathrm{~B}$, respectively. ${ }^{*}$, data from Barbeyron et al. [4].

(a)

L1

PE

AL1

AL2

L1

PE

ALl

AL2

(d)

(b)

L1

PE

AL1

AL2

L2

(e)

L1

PE

AL1

L2

AL2 (c)

L1

PE

ALl

AL2

L2

AL3

Figure 5. Two-dimensional thin-layer chromatogram of polar lipids extracted from strain 36-CHABK-3-33 ${ }^{\mathrm{T}}$. (a) Zobellia galactanivorans CIP $106680^{\mathrm{T}}$; (b) Zobellia amurskyensis $\mathrm{KMM} \mathrm{3526}^{\mathrm{T}}$; (c) Zobellia laminariae $\mathrm{KMM} 3676^{\mathrm{T}}$; (d) Zobellia russellii KMM 3677 ; (e) and Zobellia uliginosa CIP $104808^{\mathrm{T}}$; (f) PE, phosphatidylethanolamine; AL1 and AL2, unidentified amino lipids; L1-3, unidentified lipids.

\section{Conclusions}

Phylogenetic analyses based on the 16S rRNA gene sequences of members of the genus Zobellia indicated that the novel strains form a distinct lineage within the genus (Figure 1). The above-mentioned molecular distinctiveness taken together with differences in physiological and biochemical characteristics, and in polar lipid and fatty acid compositions strongly suggest the separate taxonomic status of the novel strains. On the basis of the combined phylogenetic, genotypic, chemotaxonomic, and phenotypic data presented here, we propose that the six alga-associated isolates should be classified as the representatives 
of a novel species of the genus Zobellia. Based on new data obtained in this study, emended descriptions of the species Z. amurskyensis, Z. laminariae, Z. russellii, and Z. uliginosa are also provided.

Emended description of the species Zobellia amurskyensis-the description is as given by Nedashkovskaya et al. [3] with the following emendation. The polar lipid profile consists of phosphatidylethanolamine, two unidentified aminolipids, and two unidentified lipids.

Emended description of the species Zobellia laminariae - the description is as given by Nedashkovskaya et al. [3] with the following emendation. The polar lipid profile consists of phosphatidylethanolamine, two unidentified aminolipids, and three unidentified lipids.

Emended description of the species Zobellia russellii-the description is as given by Nedashkovskaya et al. [3] with the following emendation. The polar lipid profile consists of phosphatidylethanolamine, three unidentified aminolipids, and two unidentified lipids.

Emended description of the species Zobellia uliginosa-the description is as given by description was previously given by Reichenbach for [Cytophaga] uliginosa [6] and by Barbeyron et al. [1] with the following emendation. The polar lipid profile consists of phosphatidylethanolamine, two unidentified aminolipids, and two unidentified lipids.

Description of Zobellia barbeyronii sp. nov.: Zobellia barbeyronii (bar.bey.ro'ni.i. N.L. gen. masc. n. barbeyronii, of Barbeyron, named in honor of Tristan Barbeyron, a French marine biologist and microbiologist, for his contribution to the investigation of Zobellia species).

Cells are heterotrophic, aerobic, motile by gliding, Gram-stain-negative rods, and 0.3-0.6 $\mu \mathrm{m}$ wide and 0.9-2.3 $\mu \mathrm{m}$ long. On marine agar, colonies are circular, shiny, mucous, with entire edges, 1-2 mm in diameter, dark orange and slightly sunken into agar. Growth occurs at $4-32{ }^{\circ} \mathrm{C}$ (optimum is $23-25^{\circ} \mathrm{C}$ ) and $\mathrm{pH}$ 6.0-9.0 (optimum is 7.0-8.0), and with $0.5-8 \% \mathrm{NaCl}$ (optimum is $2-3 \% \mathrm{NaCl}$ ). Natural or artificial seawater is required for growth. Catalase and oxidase activities are present. Lysine decarboxylase, ornithine decarboxylase, and tryptophan deaminase activities are absent. Aesculin, agar, gelatin, DNA, L-tyrosine, and Tweens 20 and 80 are hydrolyzed but casein, starch, and CM-cellulose are not. Hydrolysis of Tween 40 and urea, and citrate utilization are strain-dependent. Acid is produced from D-cellobiose, D-fructose, D-galactose, D-glucose, maltose, mannose, melibiose, Lrhamnose, sucrose, trehalose, D-xylose, and mannitol, but not from D-lactose, ribose, raffinose, $\mathrm{N}$-acetylglucosamine, and glycerol. In the API 20NE gallery, positive for nitrate reduction, aesculin, gelatin, and PNPG tests, assimilation of glucose, arabinose, mannose, mannitol, N-acetylglucosamine, and maltose. Utilization of gluconate, adipate, malate, citrate, and phenylalanine are strain-dependent. In the API 20E kit, ONPG and gelatin hydrolysis were positive. Arginine dihydrolase, citrate, urea, glucose, sorbitol, and melibiose tests were strain-dependent. With API $50 \mathrm{CH}$ strips positive results were obtained for oxidation of glycerol, L-arabinose, D-galactose, D-glucose, D-fructose, D-mannose, inositol, D-mannitol, methyl- $\alpha$-D-mannopyranoside, methyl- $\alpha$-D-glucopyranoside, aesculin, aesculin, D-cellobiose, maltose, D-lactose, D-melibiose, sucrose, D-trehalose, D-turanose, and D-fructose. According to the API ZYM tests, alkaline phosphatase, leucine arylamidase, cystine arylamidase, valine arylamidase, acid phosphatase, naphtol-AS-BI-phosphohydrolase, $\beta$-galactosidase, $\beta$-glucosidase, and $\mathrm{N}$-acetyl- $\beta$-glucosaminidase activities are present but lipase (C14), $\alpha$-chymotrypsin, and $\beta$-glucuronidase activities are absent. Esterase (C4), esterase lipase (C8), trypsin, $\alpha$-galactosidase, $\alpha$-glucosidase, $\alpha$-mannosidase, and $\alpha$-fucosidase activities are strain-dependent. Nitrate is reduced. Hydrogen sulphide, indole, and acetoin are not produced. The prevalent fatty acids are iso- $\mathrm{C}_{17: 0} 3-\mathrm{OH}$, summed feature 3 (comprising $C_{16: 1} \omega 7 c$ and/or iso- $C_{15: 0} 2-O H$ fatty acids), iso- $C_{15: 0}$, iso- $C_{15: 1} G$, $\mathrm{C}_{15: 0}$, and iso- $\mathrm{C}_{15: 0} 3-\mathrm{OH}$. The polar lipid profile consists of phosphatidylethanolamine, two unidentified aminolipids, and three unidentified lipids. The main respiratory quinone is MK-6. The genomic DNA G+C content of the type strain is $36.7 \mathrm{~mol} \%$.

The annotated draft genome of type strain $36-\mathrm{CHABK}-3-33^{\mathrm{T}}$ comprising $4,977,540 \mathrm{bp}$ is deposited in a public database (GenBank, NCBI) under accession number JACATN000000000.1. The type strain, 36-CHABK-3-33 ${ }^{\mathrm{T}}\left(=\mathrm{KACC} 21790^{\mathrm{T}}=\mathrm{KMM} 6746^{\mathrm{T}}\right)$, was isolated from a green 
alga Ulva sp., collected from Kraternaya Bay, Yanchich Island, Kuril Islands, the Okhotsk Sea, Russia.

Supplementary Materials: The following are available online at https: / www.mdpi.com/article / 10.3390/d13110520/s1, Table S1: MLSA primers designed based on genome sequence of the 36CHABK-3-33T used for estimation of intraspecies genetic variability, Figure S1: Maximum-likelihood (ML) phylogenetic tree based on concatenated partial dnaK-gyrB-pyrH-recA-topA (2570 bp) gene sequences, showing the phylogenetic position of six alga-associated isolates and members of the genus Zobellia, Table S2: MLSA distances values for the selected strains in this study.

Author Contributions: Isolation, morphological and biochemical characterization of strains, O.N.; chemotaxonomic characterization, N.Z.; Sanger sequencing, K.G. and V.C.; genome sequencing, phylogenetic, phylogenomic and MLSA analyses, N.O. and M.I.; resources, L.T. and V.M.; writingoriginal draft preparation, M.I., O.N. and N.Z.; manuscript editing, O.N., M.I. and V.M. All authors have read and agreed to the published version of the manuscript.

Funding: This research was funded by Grant of the Ministry of Science and Higher Education, Russian Federation 13.1902.21.0012 (contract No 075-15-2020-796).

Institutional Review Board Statement: Not applicable.

Data Availability Statement: The $16 \mathrm{~S}$ rRNA and five house-keeping gene ( $\operatorname{dnaK}, g y r B, \operatorname{pyrH}, \operatorname{rec} A$, and topA) sequences of strains 36-CHABK-3-51, 36-CHABK-3-57, 36-CHABK-3-61, 36-RHABK-5-24, and 36-RHABK-5-54 were deposited in GenBank/EMBL/DDBJ under the accession numbers from MZ890274 to MZ890278 and from MZ911872 to MZ911896, respectively. The genome sequence of strain 36-CHABK-3-33 ${ }^{\mathrm{T}}$ was deposited in GenBank under accession number JACATN000000000.1, the complete 16S rRNA and dnaK, gyrB, pyrH, recA, and top $A$ gene sequences are under locus tags HW347_20420, HW347_06625, HW347_13185, HW347_14810, HW347_03910, and HW347_00910, respectively. Strain $36-\mathrm{CHABK}-3-33^{\mathrm{T}}$ was deposited in the Collection of Marine Microorganisms (WFCC acronym is KMM) under the number KMM $6746^{\mathrm{T}}$, and in the Korean Agricultural Culture Collection (KACC) under the number of KACC $21790^{\mathrm{T}}$.

Acknowledgments: O.N. wishes to thank V.V. Kurilenko (PIBOC FEB RAS, Vladivostok, Russia) for algae sampling during 36th Cruise of R/V "Academic Oparin".

Conflicts of Interest: The authors declare no conflict of interest.

\section{References}

1. Barbeyron, T.; l'Haridon, S.; Corre, E.; Kloareg, B.; Potin, P. Zobellia galactanovorans gen. nov., sp. nov., a marine species of Flavobacteriaceae isolated from a red alga, and classification of [Cytophaga] uliginosa (ZoBell and Upham 1944) Reichenbach 1989 as Zobellia uliginosa gen. nov., comb. nov. Int. J. Syst. Evol. Microbiol. 2001, 51, 985-997. [CrossRef] [PubMed]

2. LPSN_List of Prokaryotic Names with Standing in Nomenclature. Available online: https://www.bacterio.net/ (accessed on 1 September 2021).

3. Nedashkovskaya, O.I.; Suzuki, M.; Vancanneyt, M.; Cleenwerck, I.; Lysenko, A.M.; Mikhailov, V.V.; Swings, J. Zobellia amurskyensis sp. nov., Zobellia laminariae sp. nov. and Zobellia russellii sp. nov., novel marine bacteria of the family Flavobacteriaceae. Int. J. Syst. Evol. Microbiol. 2004, 54, 1643-1648. [CrossRef] [PubMed]

4. Barbeyron, T.; Thiébaud, M.; Le Duff, N.; Martin, M.; Corre, E.; Tanguy, G.; Vandenbol, M.; Thomas, F. Zobellia roscoffensis sp. nov. and Zobellia nedashkovskayae sp. nov., two flavobacteria from the epiphytic microbiota of the brown alga Ascophyllum nodosum, and emended description of the genus Zobellia. Int. J. Syst. Evol. Microbiol. 2021, 71, 004913. [CrossRef]

5. ZoBell, C.E. A list of marine bacteria including descriptions of sixty new species. Bull. Scripps. Inst. Oceanog. Univ. Calif. 1944, 5, 239-292.

6. Reichenbach, H.; Genus, I. Cytophaga Winogradsky 1929, 577 AL emend. In Bergey's Manual of Systematic Bacteriology; Staley, J.T., Bryant, M.P., Eds.; Williams \& Wilkins: Baltimore, MD, USA, 1989; Volume 3, pp. 2015-2050.

7. Bowman, J.P. Description of Cellulophaga algicola sp. nov., isolated from the surfaces of Antarctic algae, and reclassification of Cytophaga uliginosa (ZoBell and Upham 1944) Reichenbach 1989 as Cellulophaga uliginosa comb. nov. Int. J. Syst. Evol. Microbiol. 2000, 50, 1861-1868. [CrossRef]

8. Nedashkovskaya, O.I.; Suzuki, M.; Genus, L.X.I. Zobellia. In Bergey's Manual of Systematic Bacteriology; Krieg, N.R., Ludwig, W., Eds.; Springer: New York, NY, USA, 2011; Volume 4, pp. 292-295.

9. Barbeyron, T.; Thomas, F.; Barbe, V.; Teeling, H.; Schenowitz, C.; Dossat, C.; Goesmann, A.; Leblanc, C.; Glöckner, F.O.; Czjzek, M.; et al. Habitat and taxon as driving forces of carbohydrate catabolism in marine heterotrophic bacteria: Example of the model algae-associated bacterium Zobellia galactanivorans DsijT. Environ. Microbiol. 2016, 18, 4610-4627. [CrossRef] 
10. Chernysheva, N.; Bystritskaya, E.; Stenkova, A.; Golovkin, I.; Nedashkovskaya, O.; Isaeva, M. Comparative genomics and CAZyme genome repertoires of marine Zobellia amurskyensis KMM 3526T and Zobellia laminariae KMM 3676T. Mar. Drugs 2019, 17, 661. [CrossRef]

11. Lane, D.J. 16S/23S rRNA sequencing. In Nucleic Acid Techniques in Bacterial Systematics; Stackebrandt, E., Goodfellow, M., Eds.; John Wiley \& Sons: New York, NY, USA, 1991; pp. 115-147.

12. Yoon, S.H.; Ha, S.M.; Kwon, S.; Lim, J.; Kim, Y.; Seo, H.; Chun, J. Introducing EzBioCloud: A taxonomically united database of $16 \mathrm{~S}$ rRNA gene sequences and whole-genome assemblies. Int. J. Syst. Evol. Microbiol. 2017, 67, 1613. [CrossRef]

13. Thompson, J.D.; Higgins, D.G.; Gibson, T.J. CLUSTAL W: Improving the sensitivity of progressive multiple sequence alignment through sequence weighting, position-specific gap penalties and weight matrix choice. Nucleic Acids Res. 1994, 22, 4673-4680. [CrossRef] [PubMed]

14. Kumar, S.; Stecher, G.; Tamura, K. MEGA7: Molecular evolutionary genetics analysis version 7.0 for bigger datasets. Mol. Biol. Evol. 2016, 33, 1870-1874. [CrossRef]

15. Kimura, M. A simple method for estimating evolutionary rates of base substitutions through comparative studies of nucleotide sequences. J. Mol. Evol. 1980, 16, 111-120. [CrossRef] [PubMed]

16. Huson, D.H.; Kloepper, T.; Bryant, D. SplitsTree 4.0-Computation of phylogenetic trees and networks. Bioinformatics 2008, 14, 68-73. [CrossRef] [PubMed]

17. FastQC. Available online: http://www.bioinformatics.babraham.ac.uk/projects/fastqc/ (accessed on 26 April 2018).

18. Bolger, A.M.; Lohse, M.; Usadel, B. Trimmomatic: A flexible trimmer for Illumina sequence data. Bioinformatics 2014, 30, 2114-2120. [CrossRef]

19. Bankevich, A.; Nurk, S.; Antipov, D.; Gurevich, A.A.; Dvorkin, M.; Kulikov, A.S.; Lesin, V.M.; Nikolenko, S.I.; Pham, S.; Prjibelski, A.D.; et al. SPAdes: A new genome assembly algorithm and its applications to single-cell sequencing. J. Comput. Biol. 2012, 19, 455-477. [CrossRef]

20. Gurevich, A.; Saveliev, V.; Vyahhi, N.; Tesler, G. QUAST: Quality assessment tool for genome assemblies. Bioinformatics 2013, 29, 1072-1075. [CrossRef] [PubMed]

21. Parks, D.H.; Imelfort, M.; Skennerton, C.T.; Hugenholtz, P.; Tyson, G.W. CheckM: Assessing the quality of microbial genomes recovered from isolates, single cells, and metagenomes. Genome Res. 2015, 25, 1043-1055. [CrossRef]

22. Tatusova, T.; DiCuccio, M.; Badretdin, A.; Chetvernin, V.; Nawrocki, E.P.; Zaslavsky, L.; Lomsadze, A.; Pruitt, K.D.; Borodovsky, M.; Ostell, J. NCBI prokaryotic genome annotation pipeline. Nucleic Acids Res. 2016, 44, 6614-6624. [CrossRef] [PubMed]

23. Asnicar, F.; Thomas, A.M.; Beghini, F.; Mengoni, C.; Manara, S.; Manghi, P.; Zhu, Q.; Bolzan, M.; Cumbo, F.; May, U.; et al. Precise phylogenetic analysis of microbial isolates and genomes from meta-genomes using PhyloPhlAn 3.0. Nat. Commun. 2020, 11, 2500. [CrossRef]

24. Rodriguez-R, L.M.; Konstantinidis, K.T. The enveomics collection: A toolbox for specialized analyses of microbial genomes and metagenomes. PeerJ Prepr. 2016, 4, e1900v1. [CrossRef]

25. Meier-Kolthoff, J.P.; Göker, M. TYGS is an automated high-throughput platform for state-of-the-art genome-based taxonomy. Nat. Commun. 2019, 10, 2182. [CrossRef]

26. Zhang, H.; Yohe, T.; Huang, L.; Entwistle, S.; Wu, P.; Yang, Z.; Busk, P.K.; Xu, Y.; Yin, Y. dbCAN2: A meta server for automated carbohydrate-active enzyme annotation. Nucleic Acids Res. 2018, 46, W95-W101. [CrossRef]

27. Smibert, R.M.; Krieg, N.R. Phenotypic characterization. In Methods for General and Molecular Bacteriology; Gerhardt, P., Murray, R.G.E., Wood, W.A., Krieg, N.R., Eds.; American Society for Microbiology: Washington, DC, USA, 1994; pp. $607-654$.

28. Lemos, M.L.; Toranzo, A.E.; Barja, J.L. Modified medium for the oxidation-fermentation test in the identification of marine bacteria. Appl. Environ. Microbiol. 1985, 49, 1541-1543. [CrossRef] [PubMed]

29. Fautz, E.; Reichenbach, H. A simple test for flexirubin-type pigments. FEMS Microbiol. Lett. 1980, 8, 87-90. [CrossRef]

30. Sasser, M. Identification of Bacteria by Gas Chromatography of Cellular Fatty Acids; MIDI Technical Note 101; MIDI Inc.: Newark, DE, USA, 1990.

31. Minnikin, D.E.; Patel, P.V.; Alshamaony, L.; Goodfellow, M. Polar lipid composition in the classification of Nocardia and related bacteria. Int. J. Syst. Evol. Microbiol. 1977, 27, 104-117. [CrossRef]

32. Konstantinidis, K.T.; Tiedje, J.M. Genomic insights that advance the species definition for prokaryotes. PNAS 2005, 102, 2567-2572. [CrossRef] [PubMed]

33. Richter, M.; Rosselló-Móra, R. Shifting the genomic gold standard for the prokaryotic species definition. PNAS 2009, 106, 19126-19131. [CrossRef]

34. Meier-Kolthoff, J.P.; Auch, A.F.; Klenk, H.P.; Göker, M. Genome sequence-based species delimitation with confidence intervals and improved distance functions. BMC Bioinform. 2013, 14, 60. [CrossRef]

35. Chernysheva, N.; Bystritskaya, E.; Likhatskaya, G.; Nedashkovskaya, O.; Isaeva, M. Genome-wide analysis of PL7 alginate lyases in the genus Zobellia. Molecules 2021, 26, 2387. [CrossRef]

36. Shen, J.; Chang, Y.; Zhang, Y.; Mei, X.; Xue, C. Discovery and characterization of an endo-1,3-fucanase from marine bacterium Wenyingzhuangia fucanilytica: A novel glycoside hydrolase family. Front. Microbiol. 2020, 11, 1674. [CrossRef]

37. Bernardet, J.F.; Nakagawa, Y.; Holmes, B. Proposed minimal standards for describing new taxa of the family Flavobacteriaceae and emended description of the family. Int. J. Syst. Evol. Microbiol. 2002, 52, 1049-1070. [CrossRef] 